\title{
ANALISIS YURIDIS PELAKSANAAN DIVERSI DALAM TAHAP PENYIDIKAN KEPOLISIAN DITINJAU DARI SISTEM PERADILAN PIDANA ANAK
}

\author{
SAMUEL TAMPUBOLON, PADRISAN JAMBA \\ pb160710081@upbatam.ac.id,padrisan@puterabatam.ac.id \\ Program Studi Ilmu Hukum, Universitas Putera Batam
}

\begin{abstract}
Article 1 number (1) of the law of the Republic of Indonesia Number 35 year 2014 concerning Chilid Protection states that a child is a person who is not yet 18 (eighteen) years old, also means a child who is still in the womb. And in a criminal case of child dealing with law there is a non-litigation settlement or what is often referred to as diversi. According to Article 1 number (7) of law Number 11 of 2012 concerning the Juvenile Criminal Justice System, diversi is a diversi of the settlement of child cases from criminal justice processes outside of criminal justice. Diversi is also regulated in of Diversi and Child Management. And in the investigation stage, the police must try to Juvenile Criminal Justice System. The method the athor uses is normative research that refers of Laws relating to Junvenile Justice and Child Protection. The result of this study are that children who are in conflict with the law must have a restorative justice version of diversi process.
\end{abstract}

Keywords: Children; Diversi; Criminal Justice System

\begin{abstract}
Abstrak: Pasal 1 angka (1) Undang-Undang Republik Indonesia Nomor 35 tahun 2014 tentang Perlindungan Anak menyatakan bahwa anak adalah orang yang belum berusia 18 (delapan belas) tahun, juga berarti anak yang masih dalam kandungan. Dan dalam kasus pidana anak yang berurusan dengan hukum ada penyelesaian non-litigasi atau apa yang sering disebut sebagai diversi. Menurut Pasal 1 angka (7) UU Nomor 11 Tahun 2012 tentang Sistem Peradilan Pidana Remaja, diversi adalah diversi penyelesaian kasus anak dari proses peradilan pidana di luar peradilan pidana. Diversi juga diatur dalam Diversi dan Manajemen Anak. Dan dalam tahap investigasi, polisi harus mencoba Sistem Peradilan Pidana Remaja. Metode yang digunakan pengacara adalah penelitian normatif yang merujuk pada Hukum yang berkaitan dengan Junvenile Justice dan Perlindungan Anak. Hasil dari penelitian ini adalah bahwa anakanak yang berkonflik dengan hukum harus memiliki versi keadilan restoratif dari proses diversi.
\end{abstract}

Kata kunci: Anak-anak; Diversi; Sistem keadilan kriminal

\section{A. Pendahuluan}

Anak merupakan penyambung bangsa karena dipundaknya terletak suatu beban bangsa yang belum terselesaikan oleh generasi-generasi sebelumnya. Mungkin saja sebagian kalangan, anak saat ini belum dapat bermakna apa-apa. Akan tetapi pada masa depan, anaklah yang berperan utama untuk menentukan kemana arah negara ini. Anak sebagai salah satu sumber daya manusia dan merupakana generasi penerus bangsa sudah merupakan selayaknya mendapatkan suatu perhatian khusus atau lebih dari orang tua, masyarakat, pemerintah. Hal ini bertujuan untuk mewujudkan pembinaan agar anak menjadi sumber daya manusia yang tangguh dan berkualitias. 
Anak membutuhkan rasa kasih sayang, perlindungan, pembinaan dan pengaraha yang tepat merupakan kebutuhan psikis yang paling mendasar dalam hidp dan kehidupan anak yang sebenarnya bersandar pada hati nurani orang tua. Dalam kenyataan banyak orang tua yang tidak menyadari hal ini. Yang mempengaruhi tumbuh dan kembang anak. Seorang anak yang dibesarkan dalam kehidupan berkonflik, cenderung mengalami keresahan jiwa yang dapat mendiorong anak melakukan tindakan-tindakan negatif, yang dikaetgorikan sebagai kenakalan anak. Kenakalan anak yang ditimbulkan tersebut, bahkan bisa menjurus ke arah perbuatan melawan hukum.

Pengertian anak diatur dalam pasal 1 angka 1 Undang-Undang Republik Indonesia Nomor 35 Tahun 2014 Tentang perubahan atas Undang-Undang Nomor 23 Tahun 2002 Tentang Perlindungan Anak berbunyi anak adalah seorang yang belum berusia 18 (delapan belas) tahun, termaksud anak yang masih di dalam kandungan. Setiap peraturan perundang-undangan telah mengatur sendiri mengenai defenisi kriteria anak yang tentunya sangat mempengaruhi kedudukan hukum anak dalam subjek hukum.dalam hukum Indonesia terdapat plurasim mengenai batas usia anak (Teguh, 2018). Terkait dengan anak yang bermasalah secara hukum, lahirlah UndangUndang Nomor 3 Tahun 1997 Tentang Pengadilan Anak, yang dengan segala kelemahannya telah banyak mengundang perhatian public, sehingga pada tahun 20112012 ini dibahas Rancangan Undang-Undang Sistem Peradilan Pidana Anak yang disahkan oleh DPR pada 3 juli 2012, yang kemudian menjadi Undang-Undang Nomor 11 Tahun 2012 tentang Sistem Peradilan Pidana Anak (selanjutnya disingkat UUSPPA) pada tanggal 30 juli 2012. Lembaran negara Tahun 2012 No.153 (DJamil, 2015).

Tindak pidana saat ini terjadi di masyarakat bukan saja pelakunya orang dewasa, bahkan saat ini sering kali pelakunnya adalah masih tergolong umur anak-anak. Oleh karena itu, berbagai upaya pencegahan dan penanggulangan kenakalan anak terus dilakukan oleh negara dalam hal ini pemerintah dan penegak hukum. Yaitu dengan menyelenggarakan sistem peradilan pidana anak. Simon dan Roni Wijayanto mengartikan suatu tindak pidana sebagai suatu perilaku (handeling) yang diancam dengan pidana oleh Undang-Undang, berbeda dengan hukum (onrecthmatig) dilakukan dengan keselahan (schuld) bagi seseorang yang mampu bertanggung jawab (Jamba, 2015).

Mediasi dengan suatu landasan musyawarah menuju kesepakatan damai, mendapat pengaturan tersendiri dalam beberapa produk hukum. Pengaturan alternative dalam hukum sangatlah penting, karena Indonesia adalah negara hukum. Ide awal dari adanya alternatif penyelesiaian perkara pidana adalah dikatikan dengan sifat hukum pidana itu sendiri. Hukum pidana bersifat Ultimum Remedium, menurut Van Bemmelen hukum pidana merupakan Ultimum Remedium, yaitu sebagai obat terahir. Sebisa mungkin dibatasi, artinya kalau bagian lain dari hukum tidak cukup untuk menegaskan aturan-aturan yang diakui hukum, barulah hukum pidana diterapkan. Salah satu instrument yang dipakai dalam perlindungan anak adalah hukum. Perlindungan hukum bagi anak memiliki suatu arti sebagai tindakan perlindungan hukum terhadap berbagai kekerasan dan hak-hak serta berbagai upaya yang berkaitan dengan kesejahteraan anak. Menurut Arief Gosita, perlindungan anak menggambarkan suatu usaha membentuk kondisi dan situasi yang memungkinkan pelaksanaan hak dan kewajiban anak secara manusiawi (Teguh, 2018). Penulis berpendapat oleh sebab itu, setiap hak anak harus dijunjung setinggi-tingginya demi mencapai tujuan, yaitu lahirnya generasi muda yang sehat dan untuk kelangsungan hidupan bangsa dan negara. 
Berdasarkan jurnal yang terakreditasi sinta ISSN 2337-5418 Vol. 10 No. 2 mengatakan perlindungan anak yang berkonflik dengan hukum merupakan tanggung jawab bersama aparat penegak hukum. Tidak hanya anak sebagai pelaku, namun mencakup anak sebagai korban dan saksi. Kepolisian, aparat penegak hukum yang mempunyai peranan besar dalam penangan anak yang berkonflik dengan hukum karena pintu pertama penanganan anak yang berhadapan dengan hukum. Namun dalam pelaksanaan, lebih banyak menekankan prosedur hukum positif saja tanpa mempertimbangkan kepentingan anak, akibatnya anak yang berkonflik dengan hukum mendapatkan kekerasan dan penganiayaan saat di tangkap dan proses pemeriksaan dalam menyusun berita acara pidana. Dan juga anak-anak ketika berada dalam tahanan polisi, meskipun tidak seintensif saat pemeriksaan yang oleh anak sering disebut juga diverbal dan digulung untuk mengidetifikasi kekerasn fisik yang meraka terima. Perlakuan polisi menangkap dan mengintrogasi (memeriksa perkara anak) untuk pembuatan berita acara pemeriksan sangat lekat dalam benak anak. Kenangan ini lebih membekas sebagai pengalaman buruk yang menyakitkan tanpa ada sisi positifnya bagi kepentingan anak (Abdurrachman, Sudewo, \& Permanasari, 2015)

Salah satu bentuk perlindungan anak yang berkonflik dengan hukum dengan melalu diversi. Bentuk diversi yang dimaksud untuk menghindari dan menjauhkan anak dari proses peradilan secara formal sehingga menghindari stigamtisasi terhadap anak yang berhadapan dengan hukum dan diharapkan anak dapat kembali ke dalam lingkungan sosisal secara wajar dan semula. Oleh karena itu sanggat diperlukan peran dari semua pihak dalam menciptakan hal tersebut. Proses itu bertujuan untuk terciptanya keadilan resotatif, baik bagi anak maupun korban (Hambali, 2019).

\section{B. Metodologi Penelitian}

Penelitian adalah fasilitas yangmana digunakan manusia-manusia untuk membina, menggunakan dan mengembangkan ilmu pengetahuan. Ilmu pengetahuan disusun secara runtut agar dapat ditelaah, diperiksa secara kritis, dan juga berkembang dengan didasari riset studi yang telah dilaksanakan oleh terdahulunya. Terdapat tiga macam tujuan penelitian jika dilihat secara umum yaitu bersifat pembuktian, penemuan, dan pengembangan. Penemuan mempunyai arti bahwa kumpulan data yang di dapat dari studi sifat ini ialah kumpulan data yang masih aktual dan tidak diketahui sebelumnya. Pembuktian_maksudnya adalah kumpulan data yangmana dipergunakan dalam penelitian adalah untuk dapat kiranya_membuktikan keragu-raguan atas pengetahuan atau informasi tertentu. Pengembangan_merupakan penelitian yang tujuannya untuk memperluas serta memperdalam data yang ada. Metodologi penelitian dikelompokkan berlandasakan tingkat kealamiahan (natural setting) dan tujuan objek yaang akan diteliti dalam penelitian ini. Tujuan dapat dikelompokkan menjadi studi dasar (basic research), penelitian pengembangan, dan serta penelitian terapan (applied research). Salah satu bentuk studi ialah studi yuridis normatif atau biasa disebut dengan studi kepustakaan. studi hukum normatif difokuskan untuk pendataan hukum positif, sejarah hukum, doktrin dan asas di dalam hukum, perbandingan hukum, sistematik hukum, taraf sinkronisasi hukum. Dari uraian diatas, penulis memmutuskan untuk menerapkan metodologi penelitian studi yuridis normatif dalam menulis dan juga menganalisa hasil serta pembahasan skripsi yang penulis teliti ini. Jenis metodologi penelitian ini dipilih karena kesesuaian metode penelitian dan teori yang diperlukan oleh penulis ketika menyusun jurnal ini. 


\section{Hasil Dan Pembahasan}

Peraturan perundang-undangan dalam mengatur secara materil mengenai perlindungan anak, diantarnya adalah Undang-Undang Dasar 1945, Undang-Undang Nomor 39 Tahun 1999 Tentang Hak Asasi Manusia, Undang-Undang Nomor 35 Tahun 2014 perubahan atas Undang-Undang Nomor 23 tahun 2002 Tentang Perlindungan Anak, dan secara formil serta pelaksanaan pidananya dibentuk UndangUndang Nomor 3 tahun 1997 Tentang Pengadilan Anak yang sekarang berubah menjadi Undang-Undang Nomor 11 Tahun 2012 Tentang Sistem Peradilan Pidana Anak.

Secara normatif perlindungan dan hak-hak mendapat jaminan oleh UUD 1995 pada pasal 28D ayat 2 yang mendefenisikan bahwa melindungi anak dari kekerasn dan diskriminasi. Dan dalam UU NO 39 Tahun 1999 Tentang Ham ada pasal-pasal khusus yang mengatur tentang hak-hak anak adalah pasal 52, dan pasal yang mengatur dengan jaminan terhadap yang berhadapan hukum diatur dalam pasal 66. Perlindungan dan hak-hak anak yang bermasalah dengan hukum juga dekemukan dalam UU No 35 Tahun 2014 Tentang Perlindungan Anak. Pada pasal 1 ayat 2 disebutkan bahwa perlindungan anak segala tindakan dalam menjamin dan melindungi Anak dan hakhaknya agar hidup, tumbuh, berkembang, dan berpastipasi secara optima sesuai dengan harkat dan martabat kemanusiaan, serta mendapat perlidungan dari kekerasan dan diskiriminasi.

Pendektan sistem peradilan pidana anak sejak berlakunya Undang-Undang SPPA, jauh berbeda dengan saat masih berlakunnya Undang-Undang Nomor 3 tahun 1997 Tentang Peradilan Anak, dimana Undang-Undang Nomor 3 Tahun 1997 tersebut tidak mengenal proses pengalihan penyelesian perakara yang melibatkan anak (pelaku) diluar peradilan anak yang selama ini dilalui proses persidangan, dimana istilah lebih populer saat ini dengan istilah diversi. Melalui Undang-Undang Nomor 11 Tahun 2012 diversi wajib di terapkan dalam menyelesaikan perkara pidana anak. Oleh karena itu sangat diperlukan peran serta semua pihak dalam mewujudkan hal tersebut. Berdasarkan pasal 1 angka 6 UU SPPA disebutkan bahwa keadilan restoratif adalah penyelesian perkara pidana dengan melibatkan pelaku, korban, keluarga pelaku/korban, dan pihak-pihak lain terkait untuk secara bersama-sama mencari penyelesaian yang adil dengan menekankan pemulihan kembali kepada keadaan semula, dan bukan pembalasan (Pardede, 2017).

Didalam Undang-Undang Nomor 11 tahun 2012 Tentang Sistem Peradilan Pidana Anak pada pasal 7 ayat dijelaskan bahwa diversi dalam hal tindak pidana yang dilakukan: 1) Diancam dengan pidana penjara 7 (tujuh) tahun; dan 2) Bukan merupakan pengulangan tindak pidana. Akan tetapi ada yang berbeda menurut penulis teliti dan kalau dilihat dalam tindak pidana yang dilakukan diversi dalam Peraturan Mahkamah Agung Republik Indonesia Nomor 4 Tahun 2014 Tentang Pedoman Pelaksanaan Diversi dalam Sistem Peradilan Pidana Anak yakni pada pasal 3 menyebutkan: "hakim wajib mengupayakan Diversi dalam hal anak didakwa melakukan tindak pidana yang diancamam dengan penjara dibawah 7 (tujuh) tahun atau lebih dalam bentuk surat dakwaan subsidiaritas, alternative, kumulatif maupun kombinasi (gabungan)"

Dari kedua aturan tersebut dapat kita penulis simpulkan bahwa tindak pidana yang ancaman 7 (tujuh) tahun atau lebih dalam bentuk dakwaan subsidiaritas, alternatif, maupun kombinasi (gabungan) dan bukan merupakan pengulangan tindak pidan. Diakui bahwa dalam peraturan Mahkamah Agung Republik Indonesia Nomor 4 Tahun 2014 tentang Pedoman Pelaksanaan Diversi dalam Sistem Peradilan Pidana Anak 
bahwa UU-SPPA tidak mengatur secara jelas prosedur dan tata cara atau proses beracara tahapan dan pelaksanaan diversi. Akan tetapi, ada baiknya prosedur mengenai diversi yang sudah dinyatakan dalam UU-SPPA perlu untuk dikemukan sebagai bahan dalam memahami prosedur dan pelaksanaan diversi. Pada 30 juli 2014 UndangUndanag Nomor 11 Tahun 2012 Tentang Sistem Peradilan Pidana Anak diberlakukan, setelah diundangkan adapun yang substansi yang diatur dalam UU-SPPA antar lain mengenai penempatan anak yang menjalani proses peradilan dapat ditempatkan dalam Lembaga Pembinaan Khusus Anak (LKKA), dan paling mendasar didalam UndangUndang ini adakah pengaturan secara tergas mengenai restoratif justice dan diversi, yaitu bermaksud untuk menjauhkan anak dari proes peradilan sehingga dapat menghindari stigmatisasi terhadap anak yang berhdapan dengan hukum (Dwijayanti, 2017).

Sistem peradilan pidana anak (Juvenile Justice Sytem) Adalah segala unsur sistem peradilan pidana yang terkait di dalam penanganan kasus-kasus kenakalan anak. Pertama, polisi sebagai institusi formal ketika anak berhadapan dengan sistem peradilan, yang juga menentukan apakah anak hendak dibebaskan atau proses lebih klanjut. Kedua jaksa dan lembaga pembebasan bersyarat yang juga hendak menentukan anak hendak dibebaskan atau diproses ke pengadilan anak. Ketiga, pengadikan anak, tahapan ketika anak akan ditempatakan dalam pilihan-pilihan mulai dari dibebeaskan sampai dimasukan ke dalam institusi penghukuman terahir (Teguh, 2018).

Berdasarkan pada penjelasan point-point diatas penulis berpendapat, bawha pada hakikatnya diversi itu adalah pengalihan suatu proses penyelesaian perkara anak dari proses hukum acara yang berlaku umum, ke proses penyelesian perkara anak yang mengunakan hukum acara secara khusus. Dikatakan khusus karena hukum acara yang dipakai untuk menyelesaiakn perkara anak itu bersifat istimewa namun pada hakikitnya tidak bisa lepas dari sistem peradilan pidana pada umumnya. Dalam UUSPPA telah dikemukan menurut sistem peradilan pidana anak adalah seluuruh proses akhir perkara anak yang berhadapan dengan hukum, mulai dari tahap penyelidikan sampai dengan tahap pembimbingan setelah menjalani pidana. Bahwa dalam tulisan ini juga berpedapat sistem peradilan pidana anak tidak dapat dilepaskan dari sistem peradilan pidana umumnya.

Banyaknya anak-anak pelaku tindak pidana yang dihukum penjara seharunya tidak membawa akibat perubahan signifikan atas minimnya angka kriminalitas. Dengan demikian Undang-Undang Nomor 11 Tahun 2012 Tentang Sistem peradilan Pidana Anak terbentuk dengan model restoratif justice yang implementasinya dilakukan dengan sistem diversi sebetulnya diharapkan agar penegak hukum dalam hal melakukan penyidikan dan pemerikasan kasus anak yang berkonfilk dengan hukum lebih mengutamakan dan mempertimbangakan kepentingan terbaik bagi anak (the best interest of the child) penegak hukum dalam ini kepolisian harus benar-benar ceramat menangani perkara anak yang berhadapan dengan hukum (Sengi, 2018). Penulis sangat yakin dalam penelitian ini bahwa lahirnya undang-undang sistem peradilan pidana anak yang baru adalah sebuah impian dalam menjaga optimisme bernegara. Bahwa pemerintah dan wakil rakyat masih berusa sekuat mungkin untuk bisa melahirkan kebijak politik hukum yang progresif dalam memberikan jaminan perlindungan anak, khususnya anak yang berhadapan dengan hukum. 


\section{Penutup}

Demikian kita mengetahui pelaksanaan diversi oleh lembaga kepolisan dalam ha ini penyidik anak dalam sistem peradilan pidana anak, yaitu dengan mengutamakan musyawarah, baik itu dalam musyawarah diversi pada tahap penyidikan, dihadiri oleh anak dan/atau orangtua/wali, korban, anak korban, dan/atau orangtua/wali. Dan/atau pekerja sosial dalam pasal 34 ayat 2 Peraturan Pemerintah Repbulik Indonesia Nomor 65 Tahun 2015 Tentang Pedoman Pelaksanaan diversi dan Penanganan Anak yang belum berumur 12 (dua belas) tahun. Menurut penulis kelemahan-kelemahan yang terdapat dalam pelaksanaan diversi oleh penyidik di Indonesia saat ini yaitu belum adanya model diversi sistem peradilan pidana anak oleh penyidik sehingga apabila kita melihat berita acara dan pelaksanaan diversi oleh penyidik tidak ada keseragaman. Diversi pada perkara anak perlu dilakukan penegak hukum khususnya pihak kepolisan dalam hal ini yaitu penyidik anak secara terukur dan legal berdasarkan undang-undang sistem peradilan pidana anak dalam rangak melindungi anak, anak korban, dan kepentingan masyarakat secara proprosional. Diharapan pemerintah melalui Lembaga Kepolisan harus lebih mengingkatkan jumlah penyidik anak untuk menghindari penunjukan penyidik yang melakukan penyidikan terhadap tindak pidana yang dilakukan orang dewasa pada kasus anak. Hal itu dapat merugikan anak, karena penyidik yang melakukan penyidikan terhadap tindak pidana yang dilakukan orang dewasa (bukan penyidik anak) belum tentu memahami kondisis dan jiwa anak serta kepentingan bagi anak.

\section{Daftar Pustaka}

Abdurrachman, H., Sudewo, F. A., \& Permanasari, D. I. (2015). Model Penegakan Hukum Anak Yang Berhadapan Dengan Hukum Dalam Proses Penyidikan. Pandecta, 10(11). Https://Doi.Org/10.15294/Pandecta.V10i2

Aprilianda, N. (2017). Sistem Peradilan Pidana Indonesia Teori Dan Praktik. (L. R. Bagaskoro, Ed.). Magelang: Universitas Brawijaya Press.

Arifin, L. S. K. (2016). Teori-Teori Hukum Klasik \& Kontemporer. (R. A. Awangga, Ed.). Bogor: Ghalia Indonesia.

Djamil, M. N. (2015). Anak Bukan Untuk Dihukum. Jakarta: Sinar Grafika.

Dwijayanti, M. (2017). Diversi Terhadap Recidive Anak. Rechtidee, 12.

Hambali, A. R. (2019). Hukum Dalam Sistem Peradilan Pidana ( Diversions For Children In Conflict With The Laws In The Criminal Justice System ) Abstrak. Ilmiah Kebijakan Hukum, 13, 15-30. Https://Doi.Org/10.30641/Kebijakan.2019.V13.15-30

Jamba, P. (2015). Analisis Penerapan Delik Aduan Dalam Uu Hak Cipta Untuk Menanggulangi Tindak Pidana Hak Cipta Di Indonesia. Cahaya Keadilan.

Pardede, M. (2017). Aspek Hukum Kebijakan Penyuluhan Hukum Dalam Rangka Pelaksanaan Sistem Peradilan Pidana Anak. Jurnal Penelitian Hukum De Jure.

Sengi, E. (2018). Restorative Justice Dalam Perkara Anak Di Pengadilan Negeri Tobelo. Refleksi Hukum, 2(April), 153-166.

Sinaga, D. (2017). Penegakan Hukum Dengan Pendekatan Diversi. Yogyakarta: Nusa Media Yogyakarta.

Teguh, H. P. (2018). Teori Dan Praktek Perlindungan Anak Dalam Hukum Pidana. (L.Mayasari, Ed.). Yogyakarta: C.V Andi Offset.

Widodo. (2017). Perspektif Hukum Pidana Dan Kebijakan Pemidanaan. Yogyakarta: Aswaja Pressindo. 